\title{
Hubungan Antara Kepemimpinan Transformasional Dan Komitmen Organisasi Dengan Kinerja
}

\author{
Sugeng Sriyanto, Andik Matulassy dan Eben Ezer N \\ Universitas 17 Agustus 1945 Surabaya \\ sugeng.latbang@gmail.com
}

\begin{abstract}
In the current period of globalization, business competition is getting tighter, it takes organizations that are able to move dynamically and have qualified employees. Employees are an important factor, contributing the skills to the organization needs. To that end, the organization must improve the quality of employees, so that its performance will increase and implicate the achievement of organizational goals. Performance is a behavior in the form of work performance, influenced by external and internal factors. One part of the external factor is transformational leadership and one of the internal factors is organizational commitment. The existence of these two factors will be able to give effect to employee performance in more optimal. The purpose of this study, to know the relationship between transformation leadership and organizational commitment with performance. The number of subjects in this study was 119 people, using purposive sampling technique. Result of research, there is significant relation between transformational leadership and organizational commitment with performance, $R=$ 0,695; $F=54.129 ; p=0,000$. Partially, transformational leadership is positively and significantly correlated with organizational performance and commitment related positively and significantly with performance, $r=0,603$; with $p=0.00$ and $r=0.506 ; p$ $=0.00$.
\end{abstract}

Keywords: Transformational Leadership, Organizational Commitment, Performance.

\section{PENDAHULUAN}

Pada era globalisasi yang terjadi pada saat ini, persaingan usaha sudah tidak terelakkan lagi. Persaingan tersebut ditandai dengan kompetisi bisnis yang semakin ketat antara perusahaan/ organisasi satu dengan lainnya. Agar dapat memenangkan kompetisi, dibutuhkan organisasi yang mampu bergerak dinamis, gesit, strategis, berfokus pada bidang usaha yang digeluti. Agar organisasi dapat melakukan akselerasi tersebut, perlu ditunjang sumber daya manusia yang berkualitas.

Sumber daya manusia atau karyawan menjadi faktor penting bagi perkembangan dan kemajuan dari suatu organisasi. Hal tersebut dikarenakan, karyawan memberikan kontribusi berupa kemampuan dan keterampilan yang dibutuhkan oleh organisasi. Begitu pentingnya peranan karyawan, hendaknya setiap organisasi terus meningkatkan kualitas karyawan yang dimilikinya dengan melakukan pengelolaan secara benar. Dengan meningkatnya kualitas dari karyawan akan berdampak meningkatnya kinerja yang dihasilkan. Adanya peningkatan kinerja tersebut, secara otomatis akan berimplikasi pada meningkatnya kinerja perusahaan. Kinerja karyawan menjadi kunci keberhasilan dan tercapainya tujuan organisasi. Adanya kinerja yang baik, akan mengahasilkan produktivitas yang tinggi, sehingga akan dapat menyelesaikan beban organisasi dengan efektif dan efisien, serta tercapainya tujuan organisasi.

Timpe (1993) menjelaskan, kinerja karyawan dipengaruhi dua 
faktor, yaitu eksternal dan internal. Adapun faktor eksternal yang mempengaruhi kinerja salah satunya adalah kepemimpinan, transformasional.

Kepemimpinan transformasional merupakan salah satu jenis gaya kepemimpinan yang fokus pada konsep atribusi positif dalam mencapai kinerja yang melebihi ekspektasi. Jenis gaya kepemimpinan ini dalam mempengaruhi anggotanya menggunakan cara dan pola pendekatan melalui peningkatan kepedulian terhadap pentingnya nilai, sebagai acuan dalam menyusun rencana untuk mencapai suatu hasil dan diwujudkan dengan menjalin hubungan yang baik diseluruh anggota tim, organisasi, dan pemangku kepentingan, serta dapat memilah antara kebutuhan dan keinginan yang perlu dicapai (Beck, 1980 dalam Tauber et al, 1986).

Kepemimpinan transformasional telah ditemukan memiliki pengaruh signifikan terhadap kinerja (Rao et al, 2015). Pemimpin transformasional adalah seorang pemimpin yang memiliki rasa optimis dan percaya diri tentang masa depan serta mampu mengekspresikan mengenai kebutuhan yang akan dicapai. Dengan memiliki sifat tersebut, seorang pemimpin transformasional akan dapat mendorong karyawan untuk melihat visi organisasi secara lebih bermakna, membuat karyawan lebih memahami dan mendalami pekerjaannya. Sehingga kinerja yang dihasilkan juga akan lebih baik serta berkontribusi untuk mencapai tujuan organisasi (Piccolo dan Colquitt, 2006).

Sedangkan faktor internal yang mempengaruhi kinerja, yaitu berupa hubungan kuat antara karyawan dengan organisasai, yang disebut komitmen organisasi. Hubungan tersebut diwujudkan dalam bentuk sikap keberpihakan dan loyalitas terhadap organisasi. Bentuk keberpihakan karyawan yang tinggi terhadap organisasi dapat ditengarai dari sikap dan perilaku yang ditunjukkan, adanya keyakinan yang kuat dan penerimaan terhadap nilai, tujuan, pandangan yang positif yang dilakukan secara konsisten, serta keinginan kuat untuk tetap bertahan dan menjadi anggota juga kemauan untuk mengerahkan usaha untuk kepentingan organisasi.

Berdasarkan deskripsi seperti di atas, dapat diketahui, bahwa kinerja karyawan merupakan suatu fenomena yang penting dan menarik untuk dikaji. Dengan dilakukannya kajian tentang kinerja karyawan secara komprehensif, akan didapatkan suatu kajian yang dapat digunakan sebagai referensi untuk meningkatkan kinerja karyawan guna pencapaian tujuan organisasi.

Menilik pada uraian tersebut di atas, dapat ditarik suatu rumusan masalah, antara lain, pertama, apakah ada hubungan antara gaya kepemimpinan transformasional dan komitmen organisasi dengan kinerja karyawan? Kedua, apakah ada hubungan antara gaya kepemimpinan transformasional dengan kinerja karyawan? Ketiga, apakah ada hubungan antara komitmen organisasi dengan kinerja karyawan?

Mengacu pada rumusan masalah di atas, maka tujuan penelitian ini adalah, pertama, menguji dan menganalisa secara simultan apakah ada hubungan antara gaya kepemimpinan transformasional dan komitmen organisasi dengan kinerja karyawan. Kedua, menguji dan menganalisa secara parsial apakah ada hubungan positif antara gaya kepemimpinan transformasional dengan kinerja karyawan. Ketiga, menguji dan menganalisa secara parsial apakah ada hubungan positif antara komitmen organisasi dengan kinerja karyawan. 
Terdapat beragam sudut pandang dari para tokoh dalam menjelaskan kinerja. Secara umum kinerja diartikan sebagai suatu perilaku atau perbuatan dalam bentuk prestasi kerja yang diukur dengan cara dibandingkan dengan target yang telah ditentukan, baik secara kualitas maupun kuantitas, sebagai wujud pelaksanaan fungsi-fungsi proses menejemen/organisasi secara keseluruhan, dimana dalam pelaksanaannya membutuhkan keterampilan, kemampuan, dan usaha sesuai dengan tanggung jawab dan peranannya di perusahaan/organisasi.

Terdapat empat indikator kinerja antara lain, prestasi kerja, pelaksanaan proses kerja, pengetahuan dan terampil, serta penguasaan tugas.

Kepemimpinan transformasional dipahami sebagai suatu gaya kepemimpinan yang memiliki kemampuan dalam menginspirasi para pengikutnya untuk mencapai prestasi, aktualisasi diri, hasil-hasil yang lebih besar, tujuan dan kebaikan organisasi, dengan mengesampingkan kepentingan pribadi jangka pendek serta mampu menciptakan perubahan yang signifikan terhadap diri para pengikutnya dan misi, strategi, struktur, serta budaya organisasi.

Bass dan Avolio (1994) memaparkan, terdapat lima indikator kepemimpinan transformasional, yaitu idealized influence attribute, idealized influence behavior, inspirational motivation, intellectual stimulation, dan individual consideration.

Komitmen organisasi dipahami sebagai suatu bentuk refleksi rasa suka, bangga, dan percaya, serta menerima nilai-nilai organisasi yang menimbulkan ikatan dan sikap setia dan loyal yang diwujudkan dalam bentuk keberpihakan, keinginan untuk bertahan dan tidak akan meninggalkan organisasi dan usaha yang kuat, berupa ketelibatan kerja guna mewujudkan keberhasilan serta tujuan organisasi.

Steers (1988) menyatakan, komitmen organisasi memiliki tiga indikator utama, yaitu identifikasi, keterlibatan dan loyalitas.

Mengacu ada uraian di atas, maka hipotesis dalam penelitian ini adalah:

1. Terdapat hubungan positif antara kepemimpinan transformasional dan komitmen organisasi dengan kinerja karyawan.

2. Terdapat hubungan positif antara kepemimpinan transformasional dengan kinerja karyawan.

3. Terdapat hubungan positif antara komitmen organisasi dengan kinerja karyawan.

\section{METODE}

Penelitian ini menggunakan pendekatan kuantitatif dengan menggunakan uji analisis regresi berganda. Tujuan dilakukan uji analisis tersebut adalah untuk menguji pengaruh beberapa prediktor terhadap kriterium. Adapun prediktor dalam penelitian ini meliputi kepemimpinan transformasional dan komitmen organisasi. Sedangkan kriterium adalah kinerja karyawan. Berikut akan disajikan secara konsep hubungan antara prediktor dengan kriterium.

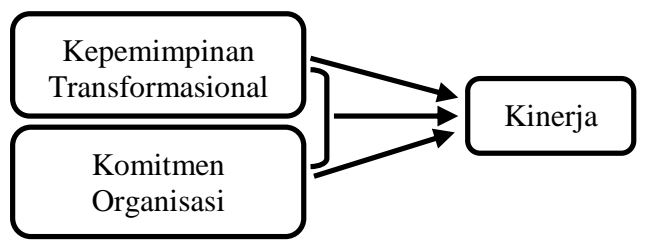

\section{Gambar 1: Konsep Hubungan Prediktor Dengan Kriterium.}

Populasi dalam penelitian ini adalah seluruh karyawan tetap PT Multi Spunindo Jaya. Sedangkan total sampel adalah 119 orang. Data penelitian dihimpun dengan menggunakan skala 
kinerja; total item 22 pernyataan, kepemimpinan transformasional; total item 23 pernyataan, dan komitmen oorganisasi; total item 16 pernyataan.

\section{HASIL}

Data yang terkumpul kemudian diolah serta dianalisis dan didapatkan hasil, nilai korelasi ganda $\mathrm{R}$ sebesar 0,695 dan nilai $\mathrm{F}=54.129$; dengan $\mathrm{p}=$ 0,000 . Nilai $\mathrm{p}<0,05$. Dari analisis koefisien korelasi $\mathrm{R}$ antara kepemimpinan transformasional dengan kinerja didapatkan hasil 0,603 dengan $p$ $=0,00$. Sedangkan koefisien korelasi $\mathrm{R}$ antara komitmen organisasi dengan kinerja didapatkan hasil 0,506 dengan $\mathrm{p}$ $=0,00$.

\section{DISKUSI}

Hasil penelitian ini berhasil membuktikan terdapat hubungan antara kepemimpinan transformasional dan komitmen organisasi dengan kinerja, terdapat hubungan antara kepemimpinan transformasional dengan kinerja, dan terdapat hubungan antara komitmen organisasi dengan kinerja.

Adanya hubungan antara kepemimpinan transformasional dan komitmen organisasi dengan kinerja, dibuktikan secara empiris dengan nilai korelasi ganda $\mathrm{R}$ sebesar 0,695 dan nilai $\mathrm{F}=54.129$; dengan $\mathrm{p}=0,000$. Nilai $\mathrm{p}<$ 0,05 .

Hasil penelitian tersebut mendukung hasil penelitian yang telah dilakukan sebelumnya oleh Dwi Elyatika (2016) pada PT Bukit Asam (Persero) Tbk Unit Tarahan, menyatakan, kepemimpinan transformasional dan komitmen organisasi berpengaruh positif serta signifikan terhadap kinerja karyawan. Pernyataan tersebut dapat diartikan, bahwa semakin tinggi gaya kepemimpinan transformasional yang dimiliki oleh stake holder/pimpinan dalam memimpin anggotanya serta komitmen organisasi yang tinggi dari para anggota, akan dapat meningkatkan kinerja karyawan.

Hasil penelitian ini juga sejalan pendapat Timpe (1993) menyatakan, bahwa kinerja karyawan dipengaruhi dua faktor, yaitu eksternal dan internal. Faktor eksternal adalah faktor yang mempengaruhi kinerja yang berasal dari luar diri seseorang. Salah satu wujud dari faktor eksternal yang mempengaruhi kinerja adalah kepemimpinan transformasional.

Kepemimpinan transformasional merupakan salah satu jenis gaya kepemimpinan yang fokus pada konsep atribusi positif yang menggunakan cara dan pola pendekatan melalui peningkatan kepedulian terhadap pentingnya nilai yang harus diciptakan dalam membuat rencana pencapaian hasil dan mewujudkannya, menjalin hubungan yang baik diseluruh anggota tim, organisasi dan seluruh pemangku kepentingan serta dapat memilah antara kebutuhan dan keinginan yang perlu dicapai (Beck Tauber et al, 2012).

Dengan menggunakan cara dan pola pendekatan gaya kepemimpinan transformasional, karyawan akan mampu menunjukkan kinerja yang tinggi, bahkan melebihi ekspektasi.

Adapun faktor internal yang mempengaruhi kinerja karyawan, yaitu berkaitan dengan karakteristik yang dimiliki oleh seseorang. Karakteristik tersebut dapat berupa kecerdasan kognitif, dan emosi. Emosi adalah satu dari dua wujud karakteristik yang menjadi faktor internal yang mempengaruhi kinerja. Komitmen organisasi merupakan salah satu bagian dari emosi.

Komitmen organisasi merupakan suatu sikap keberpihakan dan loyalitas karyawan terhadap organisasi dan tujuan organisasi (Blau \& Boal dalam Sopiah, 
2008). Adanya komitmen organisasi tinggi dari karyawan akan membentuk keyakinan yang kuat, menerima nilai dan tujuan dari organisasi, serta pandangan yang positif terhadap organisasi yang dilakukan secara konsisten. Dengan hal tersebut akan memunculkan sikap loyal, dimana karyawan bersedia untuk mendahulukan kepentingan perusahaan dari pada kepentingan dirinya sendiri.

Berdasarkan pada uraian tersebut di atas, dapat diketahui bahwa adanya dua faktor, baik eksternal berupa kepemimpinan transformasional maupun internal dalam bentuk komitmen organisasi secara bersama-sama dapat memberikan pengaruh terhadap kinerja karyawan.

Secara parsial, terdapat hubungan antara kepemimpinan transformasional dengan kinerja, dibuktikan secara empiris dengan nilai koefisien korelasi $\mathrm{R}$ sebesar 0,603 dengan $p=0,00$. Hasil penelitian tersebut sesuai dengan penelitian sebelumnya yang dilakukan oleh Basilius Redan Werang (2014) yang dilaksanakan di Kota Merauke, manyatakan kepemimpinan transformasional berpengaruh secara signifikan terhdap kinerja.

Hasil penelitian ini juga senada dengan pendapat Rao et al (2015), menyatakan pemimpin transformasional adalah seorang pemimpin yang memiliki rasa optimis dan percaya diri tentang masa depan serta mampu mengekspresikan mengenai kebutuhan yang akan dicapai.

Adanya sifat yang dimiliki oleh pemimpin transformasional tersebut, akan dapat mendorong karyawan untuk melihat visi organisasi secara lebih bermakna. Dengan kemampuan tersebut, seorang pemimpin transformasional akan membuat karyawan lebih memahami dan mendalami pekerjaannya. Sehingga kinerja yang dihasilkan juga akan lebih baik serta berkontribusi untuk mencapai tujuan organisasi (Piccolo dan Colquitt, 2006).

Selain itu, secara parsial juga ditemui adanya hubungan antara komitmen organisasi dengan kinerja, dibuktikan secara empiris dengan nilai koefisien korelasi $\mathrm{R}$ sebesar 0,506 dengan $p=0,00$. Hasil penelitian ini sesuai dengan penelitian sebelumnya yang dilakukan oleh Nur Cahyani (2010), manyatakan terdapat hubungan signifikan antara komitmen organisasi dengan kinerja.

Hasil penelitian di atas juga senada dengan pendapat Hueryren Yeh Hong (2012), menyatakan bahwa karyawan bersedia untuk tinggal dan mengabdikan diri untuk mencapai tujuan pekerjaan karena mereka memiliki nilai yang sama dan tujuan dalam organisasi, sebagai karyawan memiliki komitmen organisasi, produktifitas mereka akan meningkat dan begitu juga prestasi kerja. korelasi antara kepemimpinan transformasional dan komitmen organisasi, dimana nilai koefisien korelasi kepemimpinan transformasional lebih tinggi dibandingkan komitmen organisasi. Mengacu pada hasil tersebut, bahwa kepemimpinan transformasional memiliki hubungan yang lebih kuat dengan kinerja dibandingkan komitmen organisasi. Adanya hubungan kuat tersebut dapat dijadikan acuan dalam menentukan pilihan guna meningkatkan kinerja karyawan. Maka, kepemimpinan transformasional yang memiliki kemungkinan lebih besar dalam meningkatkan kinerja.

Hasil analisis regresi dengan variabel kepemimpinan transformasional dan komitmen organisasi sebagai prediktor dan variabel kinerja sebagai kriterium mempunyai hubungan yang signifikan. Adanya hubungan yang 
signifikan dalam penelitian ini menjadi salah satu bukti yang menunjukkan, bahwa terdapat hubungan antara kepemimpinan transformasional dan komitmen organisasi dengan kinerja. Mengingat begitu banyak variasi dari variabel yang diteliti dalam penelitian ini, maka perlu dilakukan penelitian lebih lanjut mengenai peranan dari setiap aspek maupun melibatkan variabel lain yang dapat memberikan pengaruh pada kinerja.

\section{SIMPULAN}

Secara simultan, terdapat hubungan positif kepemimpinan transformasional dan komitmen organisasi dengan kinerja. Adanya hubungan positif antara kepemimpinan transformasional dan komitmen organisasi memiliki pengaruh dalam meningkatkan kinerja. Semakin tinggi kepemimpinan transformasional yang dimiliki oleh stake holder/pimpinan yang digunakan dalam memimpin anggotanya serta komitmen organisasi yang dimiliki oleh karyawan, maka akan meningkatkan kinerja.

Terdapat terdapat hubungan positif antara kepemimpinan transformasional dengan kinerja. Secara parsial kepemimpinan transformasional memiliki pengaruh dalam meningkatkan kinerja. Sehingga, semakin tinggi kepemimpinan transformasional yang dimiliki oleh stake holder/pimpinan yang digunakan dalam memimpin anggotanya akan meningkatkan kinerja.

Selian itu, juga terdapat hubungan positif antara komitmen organisasi dengan kinerja. Secara parsial komitmen organisasi memiliki pengaruh dalam meningkatkan kinerja. Artinya, semakin tinggi komitmen organisasi dari para karyawan, maka akan berdampak pada semakin meningkatnya kinerja yang ditunjukkan.

\section{DAFTAR PUSTAKA}

A. Dale, Timpe. (1993). Kinerja. Jakarta: PT. Gramedia.

Arikunto S. (2002). Prosedur Penelitian, Suatu Pendekatan Praktek. Jakarta: PT. Rineka Cipta.

Avolio, B.J. \& Bass, B.M. (1994). Individual Consideration Viewed at Multiple Levels of Analysis: A Multilevel Framwork for Examining Te Diffusio of Transformational Leadership. Journal of Leadership Quarterly. 6(2),199-218.

Ambar T. Sulistiyani. (2003). Manajemen Sumber Daya Manusia, Cetakan Pertama. Yogyakarta: Graha Ilmu.

Anwar Prabu Mangkunegara. (2000). Manajemen Sumber Daya Manusia Perusahaan, Cetakan Ke-2. Bandung: PT. Remaja Rosda Karya.

Barry, Cushway. (2002). Human Resource Management. Jakarta. PT. Elex Media Kumputindo.

Beck Tauber, Daniela. (2012). Transformational Leadership: Exploring its Functionality (Dissertation). UniversitatasBuchbinderei Georg Konrad. Munich: $152 \mathrm{pp}$.

Burns, James MacGregor. (1978). Leadership. New York: Harper dan Row Publishers.

Cahyani, Nur. (2010). Pengaruh Profesionalisme, Kepuasan Kerja, dan Komitmen Organisasi Terhadap Kinerja Karyawan. Jurnal Bisnis dan Ekonomi, Vol 17 No. 1. Semarang: Universitas Diponegoro. 
Cheng and Jalleberg. (1996). Personalia Management (terjemahan), John Willey dan Sons,Ny, Daan Suganda. Bandung: Sinar Baru.

Daft, Richard L. (2002). Manajemen Edisi Kelima Jilid Satu. Jakarta: Erlangga.

DeVana. (1990). The Transformational Leader. New York: Jhon Wiley and Son.

Fitran M. A Ali. (2012). Kajian Pengaruh Kompetensi Terhadap Kinerja Karyawan Pada Level Jabatan Managerial Studi Kasus Pada PT. Bank Syariah ABC. Tesis tidak diterbitkan. Jakarta: Universitas Indonesia.

Gibson. (1997). Organisasi dan Manajemen, Perilaku Stuktur Proses. Jakarta: Erlangga.

Irawan. (2002). Manajemen Pemasaran Modern, Edisi Keempat. Jakarta: Liberty.

John H. Jackson. (2006). Manajemen Sumber Daya Manusia Buku I. Jakarta: Salemba Empat.

Mangkunegara, A. P. (2005). Sumber Daya Manusia perusahaan. Bandung: Remaja Rosda Karya.

Nurdin S \& Rohendi A. (2016). Gaya Kepemimpinan Transformasional, Budaya Organisasi dan Kinerja Karyawan dengan Mediasi Komitmen Organisasi. Ecodemia, Vol. IV No. 1. Bandung: Universitas BSI Bandung.

Oktara J, Rizan M, \& Situngkir S. (2017). Pengaruh Gaya Kepemimpinan Transformasional, Motivasi, serta Kompetensi terhadap Kinerja Karyawan. Jakarta: Universitas Negeri Jakarta.

ISSN : 1411-6073 (Media Cetak 2579-6321 (Media Online)
Piccolo R. F and Colquitt J. A. (2006). Transformational Leadership and Job Behaviors: The Mediating Role of Core Job Characteristics. The Academy of Management Journal, 49 (2), 327-340.

Robbins S. P \& Judge. 2008. Perilaku Organisasi, Buku 2. Jakarta: Salemba Empat

Sari D. N \& Aryanto R .(2015). Analisis Pengaruh Kepemimpinan Transformasional dan Komunikasi Internal Terhadap Motivasi dan Dampaknya Terhadap Kinerja. Tesis tidak diterbitkan. Jakarta: Binus University.

Sopiah. (2008). Perilaku Organisasi. Yogyakarta: Andi.

Steers, R., Porter, Lyman. (1983). Motivational and Work Behavior, 3th edition. Tokyo: Mc. Graw Hill Book Company.

Sugiyono. (2012). Metode Penelitian Kuantitatif Kualitatif dan $R \& D$. Bandung: Alfabeta.

Suryabrata, S. (2002). Psikologi Pendidikan. Jakarta: PT. Grafindo Perkasa Rajawali.

Veithzal R. (2004). Manajemen Sumber Daya Manusia Untuk Perusahaan Cetakan Pertama. Jakarta: PT. Raja Grafindo Persada.

Walker J. W. 1992. Human Resource Strategy. New York. Mc Grow Mell, Inc.

Werang B. R. (2014). Pengaruh Kepemimpinan Transformasional, Moral Kerja, dan Kepuasan Kerja terhadap Kinerja. Tesis tidak dipublikasikan. Merauke: Universitas Musamur Papua. 
Whitmore, J. (1997). Coaching Performance. Jakarta : PT. Gramedia Pustaka. Utama.

Yamin, Sofyan, dkk. (2011). Regresi Dan Korelasi Dalam Genggaman Anda. Jakarta: Salemba Empat.

Yammarino, F. J, W. D. Spangler \& B.M. Bass. (1993). Transformational leadership and performance: A longitudinal investigation, Leadership Quarterly, Vol.4, No.1.

Yeh, Hueryren dan Hong, Dachuan. (2012). The Mediating Effect of
Organizational Commitment on

Leadership Type and Job

Performance. Nanhua University, Taiwan.

Yosias. (2013). Pengaruh Kepemimpinan Transformasional terhadap Kinerja Karyawan melalui Komitmen Organisasional. Kalimantan Tengah: Biro Administrasi Kesra \& Kemasyarakatan Setda Kalimantan Tengah.

Yuk1. (2005). Kepemimpinan Dalam Organisasi. Jakarta : Indeks. 